210 PLA'IELET ASSOCIATED IgM AND $\mathrm{C}_{3}$ IN CHILDHOOD INFECTION Z. Katsikadamos, P. Zinn, J. Forster ${ }^{+}$)

Complement and IgM are involved in the first steps of host defence against infectious agents. During infection IgG antibodies help to fix circulating antigens to throm bocytes which is followed by the destruction of the latar. We developed a micro-ELISA for the quantitation of platelet associated IgM (PIgM) and complement ( $P C_{3}$ ): nor. mal values $(n=14$, median age 10 years $)$ : PIgM $2.4 \pm 1.4$ $\mathrm{PC}_{3} 1.5 \pm 0.9 \mathrm{fg} / \mathrm{platelet}(\bar{x} \pm$ S.D.). Out of 68 investigated children with fever 25 had a viral infection (PIgM. $9.5 \pm 2.8 * \mathrm{PC} 2.6 \pm 1.8 \%), 31$ had a bacterial infection (PIgM $8.5 \pm 1.6^{*}, \mathrm{PC}_{3} 2.7 \pm 1.9 *$ ), in 12 cases the pathogenic agent could not be identified (PIgM $3.9 \pm$ pathogenic agent could not be identified (PIgM $3.9-$ controls: $\left.{ }^{2} \mathrm{p}: \angle 0.01, * \angle 0.025\right)$. In the bacterial infection PIgM and $\mathrm{PC}_{3}$ were positively correlated $(r=0.55)$. $A$ tendency to low platelet counts in patients with high $\mathrm{PIgM}$ and $\mathrm{PC}_{3}$ failed to be statistically significant. We concluode that in childhood infection IgM and $\mathrm{C}_{2}$ also are involved in antigen removal by means of attäching it to thrombocytes. But loading of platelets with ching it to thrombocytes. But loading of platelets with
IgM and $c_{3}$ is less frequent and smalier as it is with IgG.

+) University Children's Hospital, Mathildenstrasse 1, D-7800 Freiburg, FR Germany

CELLULAR IMMUNITY IN YOUNG CHILDREN WITH ACUTE MEASLES R Dagan, M Phillip, I Sarov, O Kuperman Dept. Ped. Virology Unit and Clinic, Immunology Lab, Ben Gurion University Medical Center, Beer-Sheva, Israel.

It is traditionally believed that acute measles causes marked depression of the cellular immunity, but the mechanisms responsible for this phenomenon are not completely understood. We have studied $\mathrm{T}$-1ymphocyte markers and response to mitogens in 10 previously healthy, well nourished children under 2 years of age (range 4-23m), with acute measles (between 1 to 4 days after appearance of rash). Depressed lymphocyte counts $\left(<3000 / \mathrm{mm}^{3}\right)$ were found in 7 children. Per cent $T$ cells were found to be within normal limits in all $(44-71 \%$ mean $57 \%$ vs $57-67 \%$ in control mean $63 \%$ ). T-helper cells were within normal range as compared to controls in $8 / 10$ children (mean $35 \%$ vs $37 \%$ in controls), in whom the $\%$ suppressor cell (mean 24 vs $25 \%$ controls) and the $\mathrm{H} / \mathrm{S}$ ratio (mean $1.5 \mathrm{vs}$ mean 1.7 in controls) were also normal. In 2 children, $\mathrm{H} / \mathrm{S}$ ratio was inverted $(0.5)$ with a also normal. In 2 children, $\mathrm{H} / \mathrm{S}$ ratio was inverted (0.5) with a $(38 \%, 40 \%)$. Transformation response to PHA, Con A and PWM was tested in all 10 children. A decrease was found in 4 children (including 1 of those with decreased $\mathrm{H} / \mathrm{S}$ ratio). Our findings suggest that not all cellular immunity markers are affected in children examined during acute measles. The significance of these findings in understanding the interaction of measles virus with the immune system needs further investigation.

212 SEROLOGICAL STUDIES IN CHLAMYDIA TRACHOMATIS ASSOCIATED PNEUMONIA IN INFANTS.

A.Marton, V.Iászló, Zs.Szirmai, Zs. Szever Heim Pál Children's Hospital, The Madarász Street Hospittal for Sick Children, Budapest, Hungary

Chlamydia /C./ trachomatis harboured in the maternal genital tract can be transmitted from mother to infant during parturition. Infection of the neonate may lead to colnjunctivitis in the first life days or/and after a few weeks to atypical pneumonia with or without conjunctivitis, Serology is a most reliable approach to verification of $\mathrm{C}$. trachomatis as the causative agent in lower respiratory infection in infants between $1-6$ months of age.

In 1983-85 1 to 3 serum samples of 76 young infants with atypical pneumonia were tested for A-K serotypes of C.trachomatis antibodies with indirect microimmunofluorescent method. Detection of antibodies was also carried out in serum samples of mothers whose children had a positive serological result. Serology provided evidence for chlamydial pneumonia in 9 patients. Elevated Chlamydia-specific dial pneumonia in 9 patients. Elevated Chlamydia-specific centrations of antibodies in titres 512-8192 were found in the sera of mothers, proving genital C.trachomatis infect tion. Positive chlamydial serology in atypical pneumonia of infants defines antibacterial therapy: erythromycin is the antibiotic of choice in infantile chlamydial infection,

\section{SEPTICEMIC SALMONELLOSIS AND SCHISTOSOMA INFESTATION IN AFRICAN CHILDREN}

D. Gendrel , D. Richard-Lenoble , M. Nardou , JL Moreno ,

CUSS (Depts Paed. \& Trop. Med. ) , BP 4009 , LIBREVILLE, GABON

During a period of one year at Libreville (Gabon), we performed a rectal mucosal biopsy, searching Schistosoma Intercalatum eggs (this schistosoma sp. is known only in Central Africa) in a group of 48 children ( $1-16$ y.) hospitalized for septice mic saimonellosis . $S$ intercalatum was found in $39 / 48(81 x)$ of these patients and $21 / 55$ $(38 x, p<0.001)$ of normal population, matched for age and town districts of habitation. In 19 cases over $\mathbf{4 8}$ a typhoidic salmonella was isolated (S.typhi 12, para B 3, para C 4) and a non typhoidic salmonella in the remaining 29 (S.typhimurium 7 , enteritidis 5 ,etc...). There was no difference in the clinical expression of all cases : tuphos, myocarditis and leucopenia was also noted in non typhoidic salmonellosis associated with schistosomiasis. In 11 cases over 48 it was impossible to obtain fall of fever and disappearance of salmonella bacteriemy before antiparasitic treatment

These data show that Schistosoma intercalatum deter mine septicemic salmoneliosis, probably by fixation of bacteria on worms surface, and needs specific treatment to obtain recovery of salmonellosis in case of associated infections M. Cižman, M.Furman, T. Bufon, M.Janc. Univ.medic.Centre, Depart. of Infect.Dis .and Inst. of Microbiol., Medical faculty, Ljubl jana, Yugoslavia.

Etiology of acute diarrhoea depends on geografic and temporal distribution, age, socioeconomic and other factors. The role of bacterial pathogenes in acute non-epidemic haemorrhagic diarrhoea (h.d.) in 273 hospitalized children in different age groups was evaluated from 1.l. 1981 to 31.12 .1983 . Eighty six children hospitalized for non-enteric diseases were included as controls. Stool specimens from all patients were cultured for enteric pathogens. percent of positives

\begin{tabular}{|c|c|c|c|c|c|}
\hline $\begin{array}{l}\text { Age, /No of } \\
\text { Children / }\end{array}$ & $\begin{array}{l}0-12 \text { mos } \\
(75)\end{array}$ & $\begin{array}{l}13-24 \text { mos } \\
\text { (29) }\end{array}$ & $\begin{array}{l}3-6 \text { yrs } \\
(76)\end{array}$ & $\begin{array}{l}7-15 \text { yrs } \\
(95)\end{array}$ & $\begin{array}{l}\text { controls } \\
\text { (86) }\end{array}$ \\
\hline \multicolumn{6}{|l|}{ Pathogen } \\
\hline $\begin{array}{l}\text { C. je juni } \\
\text { Salmonellae } \\
\text { Shigellae } \\
\text { E. coli } \\
\text { Y. enterocolitica } \\
\text { 2 pathogens } \\
\text { Unknown etiology }\end{array}$ & $\begin{array}{c}33,3 \\
25,3 \\
10,6 \\
1,3 \\
0 \\
2,6 \\
26,6\end{array}$ & $\begin{array}{c}31,0 \\
17,2 \\
24,1 \\
0 \\
0 \\
10,3 \\
17,2\end{array}$ & $\begin{array}{r}6,5 \\
36,8 \\
39,4 \\
0 \\
0 \\
2,6 \\
14,4\end{array}$ & $\begin{array}{r}6,3 \\
18,9 \\
51,5 \\
1,0 \\
1,0 \\
5,2 \\
15,7\end{array}$ & $\begin{array}{l}2,3 \\
0 \\
0 \\
5,7 \\
0 \\
0 \\
1\end{array}$ \\
\hline
\end{tabular}

Present data indicate that etiology of h.d. varies considerably with age. and that bacterial cause of diarrhoea was found in approximalet: so \% of patients.

\section{EPIDEMIOLOGICAL AND CLINICAL PATTERNS OF VIRAL PNEUMONIAS}

Dres.: I. PUIG, J. NADAL, A. RETANA, M. BOSCH, V. AUSINA. We carried out a prospective study of community-acquired pneumonias in childhood (1 month to 14 years) during 1984.0f a total of 215 children, 38 were serologically diagnosed by a micromethod technique of $\mathrm{CF}$. between two paired serum sarples. We found $23 \mathrm{RSV}, 7$ influenza A virus, 5 parainfluenza 3 and 3 adenovirus infections. The majority of them $\left(88^{\circ}\right)$ were attended as out-patients.

The following patterns were statistically significative for the RSV pneumonia : age $<3$ years old, $(p<0,004)$, assistance to a day-care center $(p<0,001)$, presence of fever $(p<0,0075)$ and nasal discharge $(p<0,04)$. We detected an epidemic outbreak of RSV infection in winter months, and in March of influenza A virus.

Other host and environmental factors such as sex, obesity, congeni tal malformations, gestational age, parenteral smoking, and social class had no relationship with the diversal aetiologies. Also other signs and symptoms such as cough, malaise, vomiting, tonsillitis and pharingitis had not relevant significance.

Chest X-rays showed a slight predominance of the lower and middle right lobes with no pathognomonic features. The clinical course was satisfactory in all cases and the resolution was always complete without complications.

As conclusion we will point out the high prevalence of RSV as responsible for pneumonias in the early years and the absence of specific epidemiological and clinical patterns of them. 